\title{
Effect of disturbance on plant species diversity in moist tropical forest of eastern Nepal
}

\author{
Tilak Prasad Gautam ${ }^{1 *}$ and Tej Narayan Mandal ${ }^{\text {*** }}$ \\ ${ }^{1}$ Department of Botany, Mahendra Morang Adarsha Multiple Campus, Tribhuvan University, Biratnagar, \\ Nepal \\ ${ }^{2}$ Department of Botany, Post Graduate Campus, Tribhuvan University, Biratnagar, Nepal \\ *E-mail: tilakg673@gmail.com; *ORCID: 0000-0002-4029-8804 \\ ${ }^{* *}$ E-mail: tnmandal@gmail.com
}

\begin{abstract}
Species diversity is a key factor for the stability of ecosystems but the increasing disturbances in tropical forests resulted in the shrinkage of biological diversity. This study was conducted in undisturbed and disturbed stands of Sal (Shorea robusta Gaertn.) dominated moist tropical forest of Sunsari district, eastern Nepal in order to understand the herb, shrub and tree diversity. Present study reported the 47, 16 and 60 species of herbs, shrubs and trees, respectively. The species richness and the Shannon-Wiener index for tree species were higher in undisturbed forest (9.11 and 3.08, respectively), while the Simpson's index (index of dominance) was higher in disturbed forest $(0.11)$. On the other hand, reverse case was found for shrubs and herbs where species richness and ShannonWiener index were higher but index of dominance was lower in disturbed forest. Changes in species diversity pattern reflect the effect of disturbance.
\end{abstract}

Key words: Herb, Shrub, Tree, Sunsari District

DOI: http://dx.doi.org/10.3126/on.v16i1.

Manuscript details: Received: 02.06.2018 / Accepted: 01.08.2018

Citation: Gautam, T.P. and T.N. Mandal 2018. Effect of disturbance on plant species diversity in moist tropical forest of eastern Nepal. Our Nature 16(1): 1-7. DOI: http://dx.doi.org/10.3126/on.v16i1.21558

Copyright: ( G Gautam and Mandal 2018. Creative Commons Attribution - Non Commercial 4.0 International License.

\section{Introduction}

Species diversity is a measurement of species richness along with evenness (how evenly distributed the numbers of each species) in an ecological unit i.e. community, landscape or region. More the value of species richness, stable will be the ecosystem. The knowledge of species richness is an important factor for the biodiversity conservation. Species diversity is a key determinant of ecosystem functioning like productivity, stability and nutrient dynamics. Formation of plant communities and their species diversity in tropical forests is maintained by negative plant - soil feedback (Mangan et al., 2010), local climate and soil nutrients. Tree mortality and recruitment is the most important determining factor of species richness (Phillips et al., 1994).
Tropical forests that comprise $52 \%$ of total forests contain about two thirds of the plant species in the world. In Nepal, tropical forests are confined to the Terai and Siwaliks, and comprise about $35.6 \%$ of her area and include about 487 plant species (Shrestha et al., 2002), about $8 \%$ of the total species. Diversity of tropical forests is being reduced due to natural and anthropogenic disturbances. It also decreases the number of endemic, endangered and threatened species in an ecosystem. Overexploitation of commonly used forest species may lead to single species dominance (Sapkota et al., 2010). Loss of biological diversity is the most important consequence of the degradation of tropical forests as it influences all ecological services and the livelihood of 
people (Sagar and Singh, 2006). The effect of diversity loss is comparable or exceeds the effects of herbivory, fire and drought (Tilman et al., 2014).

In order to protect the tropical biodiversity, a better knowledge of human-modified landscapes and their relationships with species diversity and composition is needed (Galanes and Thomlinson, 2009). A lot of works have been done regarding the composition, structure and fuctioning of tropical forests, globally (Raghubansi and Tripathi, 2009; Pragasan and Parthasarathy, 2010; Rahman et al., 2010; Chaturvedi et al., 2012), as well as in Nepal (Gautam and Deove, 2006; Timilsina et al., 2007; Panta et al., 2008; Sapkota et al., 2010; Rijal and Meilby, 2012; Gautam and Mandal, 2016a; 2016b; 2016c).

It has been suggested that the best way to conserve species in tropical forests is to ensure that ecosystems continue to have the same structure and function (Walker, 1995). To maintain this, a basic knowledge of forest ecosystem is crucial. Therefore, present study is designed in undisturbed and disturbed forest stands of moist tropical forest in Sunsari district of eastern Nepal with following specific objectives: 1) to analyze the species richness, 2) to assess the effect of disturbance on the diversity and population characteristics of herb, shrub and tree species.

\section{Materials and methods \\ Study area}

The study was conducted in a Sal (Shorea robusta Gaertn.) dominated moist tropical forest of Sunsari district, eastern Nepal (latitude $26^{\circ} 41^{\prime} \mathrm{N}$ to $26^{\circ} 50^{\prime} \mathrm{N}$ and longitude $87^{\circ} 09^{\prime} \mathrm{E}$ to $87^{\circ} 21^{\prime} \mathrm{E}$ ), within the altitude range of 220 to 370 $\mathrm{m}$ above msl (Fig. 1). The forest lies in the catchment area of Koshi River, one of the largest rivers in Nepal. The total area occupied by the forest is 11394 ha. The forest is bordered by the Siwalik hill in the north and Gangetic alluvial plains in the south. The soil mainly consists of deep alfisols.

The climate is tropical and monsoon type with three distinct seasons: dry and warm summer (March to May), wet and warm rainy (June to October), and dry and cool winter (November to February). The mean monthly minimum and maximum air temperature during 2005-2014 ranged from 10.9 to $25.3^{\circ} \mathrm{C}$ and 22.6 to $33.2^{\circ} \mathrm{C}$, respectively. The average annual rainfall for the period was $1998.6 \mathrm{~mm}$ (Fig. 2).
Pronounced rainfall occurred during the months of June to September. Relative humidity was higher in rainy season with highest value in August (92\%).

The central part (core area) of the forest is relatively undisturbed, while the peripheral part is affected by disturbance activities as removal of timber, livestock grazing, fuel-wood and litter collection, tree lopping, removal of poles for house-hold constructions and forest fires.

The topstory of forest is dominated by the tropical species Shorea robusta (Dipterocarpaceae), and sub-tropical elements associated with the forests are Adina cordifolia, Careya arborea, Dillenia pentagyna, Terminalia allata, Terminalia bellirica, Terminalia chebula, Lagerstroemia parviflora etc. Clerodendron infortunatum, and Murraya koenigii are some of the main shrub species while Chromolaena odorata and Achyranthes aspera are dominant herbs.

\section{Sampling and vegetation analysis}

Central part of the forest was treated as undisturbed forest (UF), and ii) peripheral part as disturbed forest (DF). Study was conducted in UF and DF while the buffer area between two forest stands was not considered for the study. Altogether, seventy permanent experimental plots, thirty five each in UF and DF were randomly established. In the present study stem of tree-species having $\geq 10 \mathrm{~cm}$ girth at breast height $(\mathrm{GBH})$ were considered as trees (Lalfakawma, 2009). For the analysis of trees, sampling plot of $20 \mathrm{~m}$ x $20 \mathrm{~m}$ was used while for shrubs nested quadrat of $5 \mathrm{~m} \times 5 \mathrm{~m}$ and for herbs nested quadrat of $1 \mathrm{~m} \times 1 \mathrm{~m}$ was established in the forest. Plant species recorded in all plots were identified with the help standard literatures and herbarium specimens deposited at Tribhuvan University Regional Herbarium, Post Graduate Campus, Biratnagar, Nepal. Species diversity parameters like species richness (Margalef, 1958), Shannon-Wiener index (Shannon and Weaver, 1963), equitability (evenness) (Pielou, 1966) and Simpson index (Simpson, 1949) were determined.

\section{Results and discussion \\ Herb and shrub diversity}

Among the total 47 species of herbs, 26 species were present in both undisturbed and disturbed forests, while 30 species were enumerated from undisturbed forest (UF) and 43 species from disturbed forest (DF) (Gautam and Mandal, 


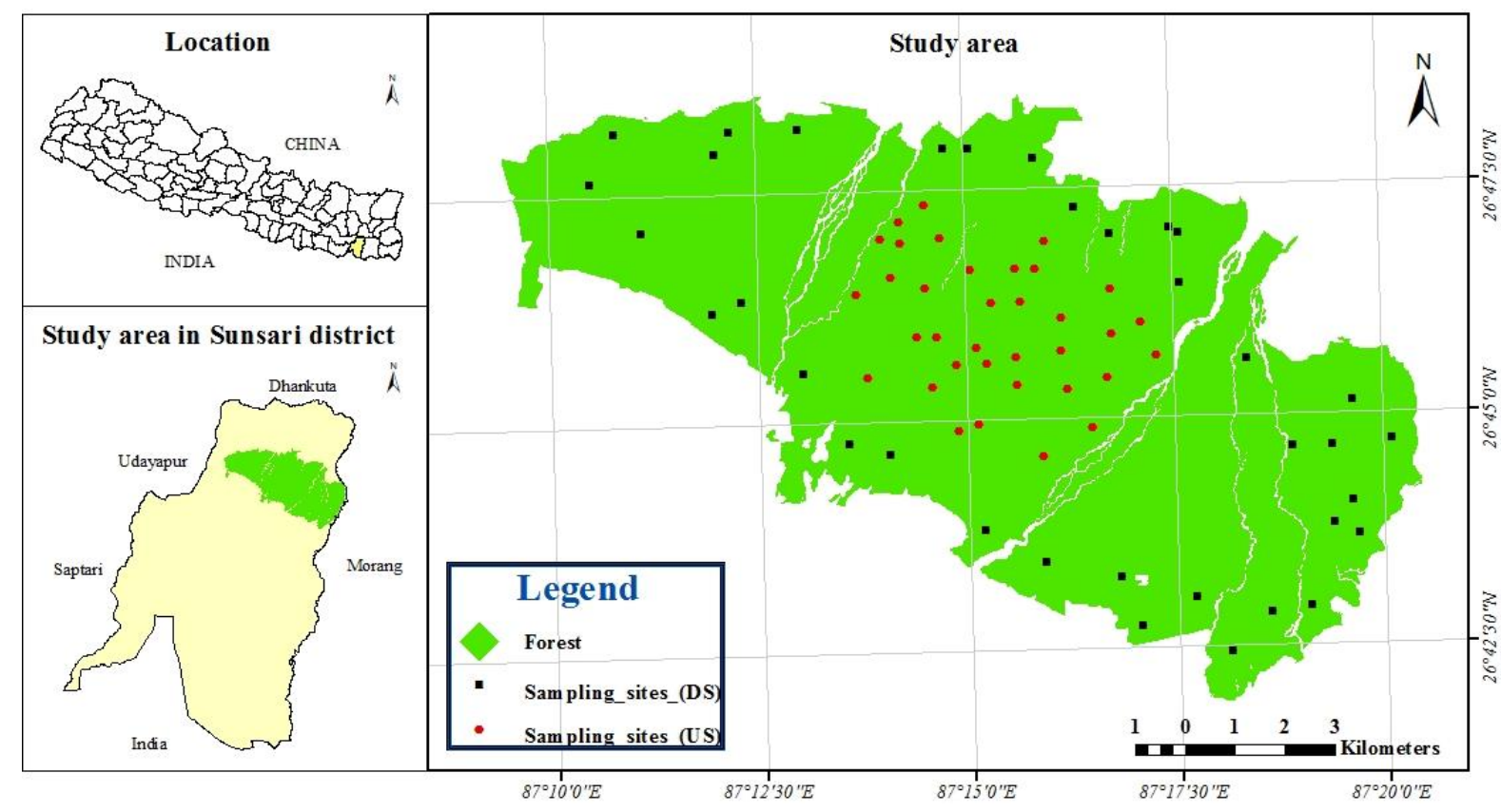

Figure 1. Map of the study area (tropical forest of Sunsari district, eastern Nepal).

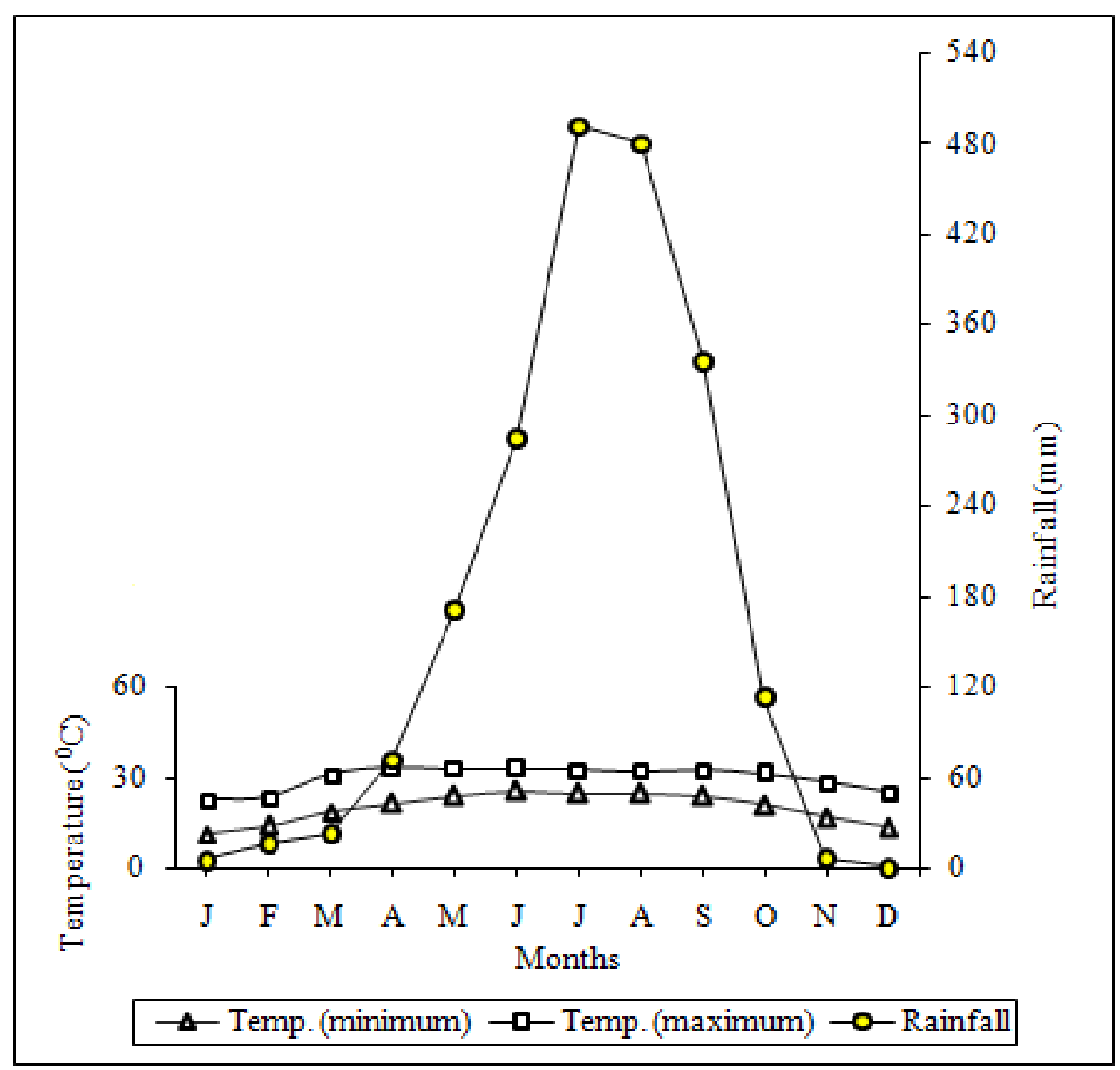

Figure 2. Ombrothermic representation of the climate of moist tropical forest region of Sunsari district, eastern Nepal. The data pertain to the period 2005-2014 (Source: Department of Meteorology, Dharan, Nepal). 
2016d). Herbaceous diversity (Shannon-Weiner index) and species richness were lower (Table 1) at UF (2.84 and 9.65, respectively). These parameters increased with forest disturbance and reached to 3.2 and 11.52 , respectively when the concentration of dominance was conversely minimum (0.05).

Altogether, 16 species of shrubs were recorded in the forest. Among them, 12 species were found in UF and 15 in DF and 11 species were common to both forests (Gautam and Mandal, 2016d). Both species diversity and species richness of shrub increased in DF as compared to UF, while the Index of dominance decreased in DF (Table 1).

Table 1. Diversity parameters of trees, shrubs and herbs components in undisturbed and disturbed forest stands of moist tropical forest of Sunsari district, eastern Nepal.

\begin{tabular}{|c|c|c|}
\hline \multirow{2}{*}{ Parameters } & \multicolumn{2}{|l|}{ Forest stands } \\
\hline & Undisturbed & Disturbed \\
\hline \multicolumn{3}{|c|}{ Species richness $(d)$} \\
\hline Trees & 9.11 & 6.78 \\
\hline Shrubs & 1.26 & 1.81 \\
\hline Herbs & 9.65 & 11.52 \\
\hline \multicolumn{3}{|c|}{$\begin{array}{l}\text { Shanon-Wiener } \\
\text { index }\left(H^{\prime}\right)\end{array}$} \\
\hline Trees & 3.08 & 2.80 \\
\hline Shrubs & 1.90 & 2.22 \\
\hline Herbs & 2.84 & 3.20 \\
\hline \multicolumn{3}{|c|}{ Equitability (e) } \\
\hline Trees & 0.76 & 0.77 \\
\hline Shrubs & 0.77 & 0.78 \\
\hline Herbs & 0.84 & 0.85 \\
\hline \multicolumn{3}{|c|}{$\begin{array}{l}\text { Index of } \\
\text { dominance }(c)\end{array}$} \\
\hline Trees & 0.08 & 0.11 \\
\hline Shrubs & 0.18 & 0.13 \\
\hline Herbs & 0.08 & 0.05 \\
\hline
\end{tabular}

Forest disturbances resulted in an increase in herb and shrub species diversities. ShannonWiener index of herbaceous species increased to 3.20 in disturbed forest (DF) Vs 2.84 in undisturbed forest (UF). Generally, the species diversity increases with the development of secondary communities (Odum, 1969). Herb and shrub species content, density, species richness and species diversity increased in DF. It is in accordance with the "Intermediate Disturbance Hypothesis" which stated that under intermediate levels of disturbance diversity is highest (van der Marrel, 1993).

\section{Tree layer diversity}

In the present study, 981 individuals of trees were recorded which belonged to 60 species, 51 genera, and 32 families (Gautam and Mandal, 2016d). Out of these, 57 species were present in $\mathrm{UF}, 38$ in DF and 35 were common to both forest stands. In the present forest, 6-10 tree species were observed in most of the quadrats (20 in UF and 15 in DF) (Fig. 3). In the same way, 11-15 species were found only in 10 quadrats of UF. This also indicates the contagious dispersion pattern of species.

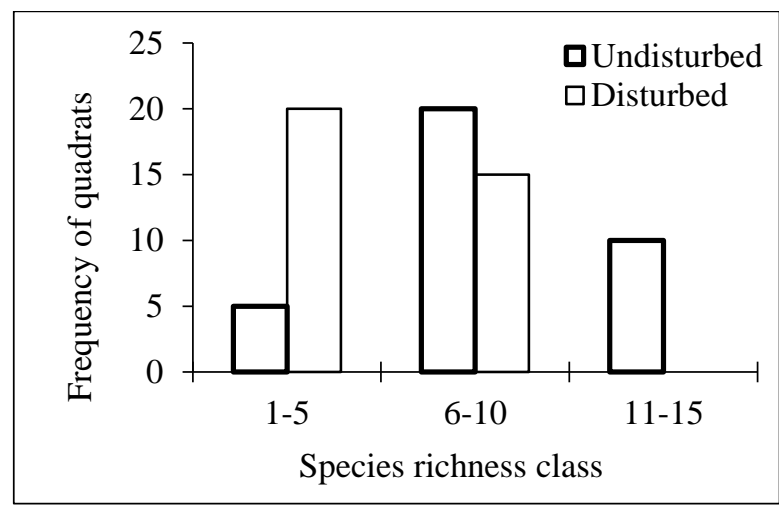

Figure 3. Spatial distribution of species richness in undisturbed and disturbed forest stands of moist tropical forest in Sunsari district, eastern Nepal.

Diversity parameters for trees revealed that the species richness and the Shannon-Wiener index $\left(H^{\prime}\right)$ for tree species were higher in UF, while the Simpson's index was higher in DF (Table 1). It showed that concentration of dominance was higher in DF which was inversely related to Shanon-Wiener index. On the other hand, reverse case was found for shrubs and herbs where species richness and ShannonWiener index were higher but index of dominance was lower in DF. Changes in species diversity pattern reflect the effect of disturbance.

Diversity indices reflect the manner in which abundance is distributed among the different species constituting the community. Species diversity is often correlated with rainfall, nutrient status and disturbance level.

The equitability or evenness refers to the degree of relative dominance of each species in that area. The equitability of trees in the present forest ( 0.76 in UF and 0.77 in DF) is higher to matured Sal forest of eastern Siwaliks, Nepal (0.69; Mandal, 1999) and sub-tropical humid 
forests of Meghalaya, India (0.53 in UF and 0.61 in DF, Upadhaya et al., 2004); whereas lower to the wet tropical evergreen forests of Western Ghats, India (1.3-2.4, Swamy et al., 2010).

In the present study, Simpson's index (index of dominance or concentration of dominance) of trees was higher in DF (0.11) than in UF (0.08). It happens due to sharing of large portion of resources by few species only (Singh and Singh, 1991a; Swamy et al., 2010) or connected to the dominance of disturbance tolerable species like Shorea robusta, in the present forest. Moreover, it may be attributed to the restrictions imposed by policy on cutting important timber species.

Shorea robusta has ability to re-sprout aggressively from root suckers after short duration of disturbances (Gautam and Devoe, 2006; Sapkota et al., 2009a). It has proved to be more aggressive than its competitors with its resistance to forest fires and other external factors through the die- back mechanism (Champion and Seth, 1968). It may be attributed to high light demanding character of Sal; disturbance mediated light availability favors its seedling recruitment process (Sapkota et al., $2009 \mathrm{~b}$ ). On the other hand, repeated removal of fodder and fuel-wood species lead to single species dominance in the forest (Sapkota et al., 2010).

Moreover, some co-dominant species like Haldina cordifolia, Schleichera oleosa and Alangium salvifolium also occur in the DF. It may be due to their ability to compete with dominant species for space and resources and also the result of less preference given by the local people for their exploitation (Sapkota et al., 2010). The Simpson's index in this study is lower as compared to tropical dry evergreen forest of Coromandel Coast of India (0.14-0.53; Anbarashan and Parthasarathy, 2013), whereas it is nearly equal to the tropical wet forests of Western Ghat, India (0.1; Swamy et al., 2010) but quite higher to the sub-tropical humid forests of Meghalaya, India (0.034 in DF and 0.067 in UF; Upadhaya et al., 2004).

The Shannon-Wiener index combines the variety and equitability components but it may obscure the individual behavior of two components since an increase in the equitability may counteract a decrease in number of species. This index increased with an increase in number of species. The higher $H^{\prime}$ index compared to the

Simpson's index indicates an inverse relationship between these two indices. The higher $H^{\prime}$ index in UF of present study may be due to the microclimatic and soil nutrient availability which have direct impact on the spatial diversity of vegetation. The ShannonWiener index $\left(H^{\prime}\right)$ for the tree species in the present forest is comparable to the several tropical and subtropical forests of Asia (Table 2).

Table 2. Shannon-Wiener index $\left(H^{\prime}\right)$ for the tree species in tropical and subtropical forests of Asia.

\begin{tabular}{|c|c|c|}
\hline $\begin{array}{l}\text { Forests and } \\
\text { localities }\end{array}$ & $H^{\prime}$ index & References \\
\hline $\begin{array}{l}\text { Tropical Plateau } \\
\text { Sal, eastern Nepal }\end{array}$ & 1.66 & Mandal (1999) \\
\hline $\begin{array}{l}\text { Tropical dry } \\
\text { evergreen, India }\end{array}$ & $1.24-2.2$ & $\begin{array}{l}\text { Anbarashan and } \\
\text { Parthasarathy } \\
\text { (2013) }\end{array}$ \\
\hline $\begin{array}{l}\text { Subtropical, } \\
\text { Meghalaya, India }\end{array}$ & $3.42-3.87$ & $\begin{array}{l}\text { Upadhaya et al. } \\
\text { (2004) }\end{array}$ \\
\hline $\begin{array}{l}\text { Tropical wet, } \\
\text { Bangladesh }\end{array}$ & 3.37 & $\begin{array}{l}\text { Feroz et al. } \\
(2013)\end{array}$ \\
\hline $\begin{array}{l}\text { Tropical wet, } \\
\text { western Ghats, } \\
\text { India }\end{array}$ & $2.01-3.7$ & $\begin{array}{l}\text { Swamy et al. } \\
(2010)\end{array}$ \\
\hline $\begin{array}{l}\text { Tropical moist, } \\
\text { eastern Nepal }\end{array}$ & 3.08 & Present study \\
\hline
\end{tabular}

Species richness or variety index $(d)$ is the mean number of species per unit area. The tree species richness of the present forest (6.78 in DF- 9.11 in UF) is lower to the tropical wet evergreen forests of Western Ghat, India (7.912.7, Swamy et al., 2010). The number of tree species reduced by $33.3 \%$ in DF as compared to UF. The higher species richness in UF may be due to higher soil moisture and nutrients. On the other hand, less number of species in DF is attributed to frequent and fluctuating disturbances and also to the responses of species to such disturbances. The species richness of present forest is quite higher to the matured Plateau Sal forest of eastern Siwaliks, Nepal (1.57; Mandal, 1999). Higher species richness in the present forest as compared to dry forests might be due to higher value of annual precipitation. The degree of natural disturbance has often been considered as a critical factor in determining tropical forest species diversity. Anthropogenic disturbances, such as burning, grazing, and wood collection, may have significantly lowered plant species richness in DF.

\section{Conclusions}

The changes in species diversity pattern reflect the moderate type of disturbance in the present 
forest. Lower value of tree species richness in the disturbed forest indicates that trees are under great pressure of anthropogenic disturbances. On the other hand, forest disturbance favours the richness of herb and shrub species reflecting greater ability to tolerate the disturbances as compared to trees. It might be associated with the availability and utility of light under canopy and open space or lower interest of local peoples towards the utilization of herbs and shrubs as compared to trees. Finally, proper conservation and management actions should be taken immediately by concerned authorities to protect the endemic, endangered and threatened species in an ecosystem.

\section{Acknowledgements}

The authors are grateful to the Head, Department of Botany, Post Graduate Campus, T.U., Biratnagar, Nepal for providing laboratory and library facilities. The first author is grateful to the Institute of Science and Technology, Tribhuvan University, Kathmandu for $\mathrm{Ph}$. D. study leave and to the University Grants Commission, Nepal for the research fellowship. We also acknowledge the help of Prof. Dr. S.K. Rai, Dr. K.P. Bhattarai and R.K. Rai for their help in data collection.

\section{References}

Anbarashan, M. and N. Parthasarathy 2013. Tree diversity of tropical dry evergreen forests dominated by single or mixed species on the Coromandel coast of India. Tropical ecology 54(2): 179-190.

Champion, H.G. and S.K. Seth 1968. A Revised Survey of the Forest Types of India. Government of India Publications, New Delhi.

Chaturvedi, R.K., A.S. Raghubanshi and J.S. Singh 2012. Effect of grazing and harvesting on diversity, recruitment and carbon accumulation of juvenile trees in tropical dry forests. Forest Ecology and Management 284(0): 152-162. DOI: 10.1016/j.foreco.2012.07.053

Feroz, S.M., Md.R. Alam, P. Das and A.A. Mamun 2013. Community ecology and spatial distribution of trees in a tropical wet evergreen forest in Kaptai national park in Chittagong Hill Tracts, Bangladesh. Journal of Forestry Research 24: 25-32. DOI: 10.1007/s11676013-0423-0

Galanes, I.T. and J.R. Thomlinson 2009. Relationships between spatial configuration of tropical forest patches and woody plant diversity in northeastern Puerto Rico. Plant
Ecology 201: 101-113. DOI: 10.1007/978-90481-2795-5_9

Gautam, K.H. and N.N. Devoe 2006. Ecological and anthropogenic niches of Sal (Shorea robusta Gaertn. f.) forest and prospects for multiple-product forest management - A review. Forestry 79: 81-101. DOI: 10.1093/forestry/cpi063.

Gautam, T.P. and T.N. Mandal 2016b. Fine root biomass and production in tropical moist forest of eastern Nepal. International Journal of Ecology and Environmental Sciences 42(S): 29-41.

Gautam, T.P. and T.N. Mandal 2016d. Effect of disturbance on plant species abundance and density distribution in tropical forest of Sunsari district eastern Nepal. Nepalese Journal of Biosciences 6(1): 1-12.

Gautam, T.P. and T.N. Mandal 2016a. Effect of disturbance on biomass, production and carbon dynamics in moist tropical forest of eastern Nepal. Forest Ecosystems 3: 2-10.DOI: 10.1186/s40663- 016-0070-y.

Gautam, T.P. and T.N. Mandal 2016c. Effect of disturbance on litter dynamics in moist tropical forest of eastern Nepal. Our Nature 14(1):1-12. DOI: 10.3126/on.v14i1.16435

Mandal, T.N. 1999. Ecological analysis of recovery of landslide damaged Sal forest ecosystem in Nepal Himalaya. Banaras Hindu University, Varanasi, India. (Ph.D. thesis).

Mangan, S.A., S.A. Schnitzer, E.A. Herre, K.M.L. Mack, M.C. Valencia, E.I. Sanchez and J.D. Bever 2010. Negative plant-soil feedback predicts tree-species relative abundance in a tropical forest. Nature 466: 752-756. DOI: 10.1038/nature09273

Margalef, R. 1958. Information theory in ecology. General Systematics 3: 36-71.

Odum, E.P. 1969. The strategy of ecosystem development. Sciencec 164: 262-270.

Panta, M., K. Kim and C. Joshi 2008. Temporal mapping of deforestation and forest degradation in Nepal: Applications to forest conservation. Forest Ecology and Management 256(9): 1587-1595. DOI: $10.1016 /$ j.foreco.2008.07.023

Phillips, O.L., P. Hall, A.H. Gentry, S.A. Sawyer and R. Vásquez 1994. Dynamics and species richness of tropical rain forests. Proceedings of the National Academy of Sciences of the United States of America 91(7): 2805-2809.

Pielou, E.C. 1966. The measurement of diversity in different types of biological collections. Journal of Theoretical Biology 13: 131-144. 
Pragasan, L.A. and N. Parthasarathy 2010. Landscape-level tree diversity assessment in tropical forests of southern Eastern Ghats, India. Flora-Morphology, Distribution, Functional Ecology of Plants 205(11): 728737. DOI: 10.1016/j.flora.2010.04.011

Raghubansi, A.S. and A. Tripathi 2009. Effect of disturbance, habitat fragmentation and alien invasive plants on floral diversity in dry tropical forests of Vindhyan highland: a review. Tropical ecology 50(1): 57-69.

Rahman, M.M., Md.M. Rahman, Z. Guogang and K.S. Islam 2010. A review of the present threats to tropical moist deciduous Sal (Shorea robusta Gaertn. f.) forest ecosystem of central Bangladesh. Tropical Conservation Science 3(1): 90-102. DOI: $10.1177 / 194008291000300108$

Rijal, A. and H. Meilby 2012. Is the life-supporting capacity of forests in the lower Mid-Hills of Nepal threatened? Forest Ecology and Management 283(0): 35-47.

Sagar, R. and J.S. Singh 2006. Tree diversity, basal area, and species diversity in a disturbed dry tropical forest of northern India: implications for conservation. Environmental Conservation 33: 18. DOI: 10.1017/S0376892906003237

Sapkota, I.P., M. Tigabu and P.C. Odén 2009b. Spatial distribution, advanced regeneration and stand structure of Nepalese Sal (Shorea robusta Gaertn. f.) forests subject to disturbances of different intensities. Forest Ecology and Management 257(9): 1966-1975. DOI: 10.1016/j.foreco.2009.02.008

Sapkota, I.P., M. Tigabu and P.C. Odén 2010. Changes in tree species diversity and dominance across a disturbance gradient in Nepalese Sal (Shorea robusta Gaertn.f.) forests. Journal of Forestry Research 21: 2532. DOI: $10.1007 / \mathrm{s} 11676-010-0004-4$

Sapkota, I.P., M. Tigabu and P.C. Odén 2009a. Species diversity and regeneration of oldgrowth seasonally dry Shorea robusta forests following gap formation. Journal of Forestry Research 20: 7-14. DOI: 10.1007/s11676-0090002-6
Shannon, C.E. and W. Weaver 1963. The Mathematical Theory of Communication. University of Illinois Press, Urbana.

Shrestha, T.B., J.P.B., Lilleso, L.P. Dhakal and R. Shrestha 2002. Forest and Vegetation Types of Nepal. Ministry of Forests and Soil Conservation, HMG/Nepal, Natural resource Management Sector Assistance Programme (NARMSAP), Tree Improvement and Silviculture Component, Kathmandu, Nepal.

Simpson, E.H. 1949. Measurement of diversity. Nature 163: 688.

Singh, L. J.S. Singh 1991a. Species structure, dry matter dynamics and carbon flux of a dry tropical forest in India. Annals of Botany 68: 263-273.

Swamy, S.L., C.B.S. Dutt, M.S.R. Murthy, A. Mishra and S.S. Bargali 2010. Floristics and dry matter dynamics of tropical wet evergreen forests of Western Ghats, India. Current Science 99: 353-364. DOI 10.1007/s11676-014-0471-0

Tilman, D., F. Isbell and J.M. Cowles 2014. Biodiversity and Ecosystem Functioning. Annual Review of Ecology Evolution and Sysematics 45: 471-493. DOI: 10.1146/annurev-ecolsys-120213-091917

Timilsina, N., M.S. Ross and J.T. Heinen 2007. A community analysis of sal (Shorea robusta Gaertn. f.) forests in the western Terai of Nepal. Forest Ecology and Management 241(1-3): 223-234. DOI: 10.1016/j.foreco.2007.01.012

Upadhaya, K., H.N. Pandey, P.S. Law and R.S. Tripathi 2004. Diversity and population characteristics of woody species in subtropical humid forest exposed to cultural disturbances in Meghalaya, Northeast India. Tropical ecology 45: 303-314.

van der Maarel, E. 1993. Some remarks on disturbance and its relations to diversity and stability. Journal of Vegetation Science 4: 733736.

Walker, B.H. 1995. Conserving biodiversity through ecosystem resilience. Conservation Biology 9: 747-752. 